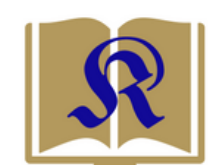

KURIOS
KURIOS

(Jurnal Teologi dan Pendidikan Agama Kristen)

ISSN 2615-739X (print), 2614-3135 (online)

Vol. 5, No. 2, Oktober 2019 (166-174)

http://www.sttpb.ac.id/e-journal/index.php/kurios

\title{
Memahami Penyembuhan Orang Buta dalam Yohanes 9:1-40 dengan Pendekatan Poskolonial
}

\author{
Vincent Kalvin Wenno \\ Prodi Teologi, Institut Agama Kristen Negeri Ambon, Maluku \\ vincentkalvin@gmail.com
}

\begin{abstract}
One of the important efforts in the postcolonial approach to biblical interpretation of the Bible is the emergence of other voices which so far have been marginalized due to the dominance of the structure or, and of a nation. The study is used in biblical texts, to see how domination takes place in text and interpretation, by seeing hegemonic power in a structure of society. The other voices to be raised in this article are the voices of persons with disabilities, especially in the text of John 9: 1-40. The text describes a long narrative about the miracle of healing a child who was born blind, who at the same time became a figure, who dared to voice his existence and identity, in the midst of fierce dialogue with Jews and Pharisees. In this narrative there is an attempt to read and interpret the text of John 9: 1-40 using the postcolonial approach.
\end{abstract}

\begin{abstract}
Abstrak
Salah satu upaya penting dalam pendekatan postkolonial pada penafsiran Alkitab adalah memunculkan suara liyan yang selama ini termarjinalisasi akibat dominasi struktur atau, dan dari suatu bangsa. Studi tersebut digunakan ke dalam teks-teks Alkitab, untuk melihat bagaimana dominasi itu terjadi di dalam teks dan penafsiran, dengan cara melihat kuasa yang hegemonik dalam suatu struktur masyarakat tersebut. Suara liyan yang hendak dimunculkan di dalam artikel ini adalah suara dari para penyandang disabilitas terutama di dalam teks Yohanes 9:1-40. Teks tersebut mendeskripsikan narasi panjang tentang mukjizat penyembuhan anak yang terlahir buta, yang sekaligus menjadi tokoh, yang berani menyuarakan keberadaan dan identitasnya, di tengah dialog yang sengit dengan orang Yahudi dan Farisi. Dalam narasi inilah ada upaya untuk membaca dan menafsirkan teks Yohanes 9:1-40 dengan menggunakan pendekatan postkolonial.
\end{abstract}

https://doi.org/10.30995/kur.v4i1.114

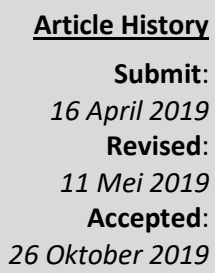

Submit:

16 April 2019

Revised:

11 Mei 2019

Accepted:

26 Oktober 2019

Keywords

(kata kunci):

disability;

John 9;

Postcolonial

approach;

disabilitas;

pendekatan

poskolonial;

Yohanes 9

\section{Pendahuluan}

Postkolonial merupakan bentuk baru dari kolonialisasi yang dianggap sudah berakhir. Kolonialisasi dalam arti yang baru, tidak lagi melakukan penaklukan terhadap suatu wilayah, tetapi mengambil bentuk baru yaitu penindasan dari satu kelompok atau bangsa tertentu, yang 
menguasai semua segi kehidupan sosial, ekonomi kultur, dari bangsa lain yang kena akan imbas dari dominasi tersebut. ${ }^{1}$

Sebagai bangsa yang pernah dijajah studi postkolonialisme menjadi pendekatan yang sangat signifikan memberikan kontribusi penting bagi perkembangan keilmuan di Indonesia. Mengingat, postkolonialisme sebagai suatu pendekatan mengangkat kembali kesadaran akan dominasi dari budaya "barat" yang dulu dan sekarang melakukan dominasi secara masif dan terstruktur terhadap dunia Timur dan Selatan. Hal ini berdampak pada hilangnya suara-suara minor yang termarjinalkan, dan tidak diberi kesempatan untuk didengar dan diberi akses. Dominasi tersebut, terjadi juga di dalam dunia pendidikan yang sangat bernuansa kebaratbaratan atau atau sangat Eropasentris, dalam artian sebagai penentu pengertian dan makna tunggal, sehingga locus pengetahuan yang berasal di luar itu diberi ruang yang selayaknya.

Upaya yang dilakukan oleh studi postkolonial adalah mengkritisi budaya kolonial pada daerah setelah jajahan, sekaligus mengembalikan kembali suara yang termarjinalkan untuk didengar. Suara ini berangkat dari pengalaman lokal masyarakat dengan tidak mengesampikan kenyataan bahwa kebudayaan itu sendiri mengalami percampuran. Untuk itu, studi dan pendekatan postkolonial mengkritisi sekaligus memperbaharui budaya kolonial sekaligus budaya lokal itu sendiri. Keduanya memiliki pengaruh dan potensi yang seimbang.

Pendekatan postokolonial ini menjadi kerangka yang digunakan bagi penafsiran dan pendekatan terhadap teks Alkitab. Menurut Sugitaharajah ${ }^{2}$, postkolonial dapat menjadi suatu interpretasi yang mengkritik bentuk dominasi budaya yang terkandung dan terlekat di dalam teks Alkitab dan sekaligus penafsiran teks Alkitab yang sangat bernuansa Barat. Hal ini mengakibatkan suara lain diabaikan dan ditindas sedemikian rupa, sehingga menjadi hilang di dalam teks atau penafsiran teks Alkitab itu sendiri. Dengan menggunakan interpretasi Postkolonial, Sugitaharajah ${ }^{3}$ menyebutkan, bahwa suara yang termarjinalkan itu tidak lagi menjadi objek dari penafsiran melainkan subjek penafsiran teks Alkitab. Untuk itu, hal yang perlu dilakukan dalam membuat interpretasi postkolonial, adalah dengan membuka singkap dan mempertanyakan keterlibatan Alkitab dalam mendukung diskriminasi, dominasi tunggal, penindasan, dan berbagai hal yang mengeksploitasi segi kehidupan manusia dalam sepanjang sejarah dan waktu.

Bentuk dari penindasan atau kolonilisasi baru adalah memasukan semua identitas ke dalam suatu struktur yang besar. Akhirnya, suara lain dari sang liyan tidak terdengar dibandingkan dengan struktur yang mendominasi dan menjadi hegemoni. Suara itu datang dari perempuan, anak-anak, LGBT, penyandang disabilitas, kaum diaspora, bahkan lingkungan alam sekitar. Terhadap suara-suara seperti itulah, saya merasa perlu untuk mengembangkan dan mengkritisi kembali teks bahkan penafsiran, yang mengakibatkan distorsi pemahaman para pendengar atau orang yang memahami Alkitab. Karena, teks Alkitab juga berisikan ikatan kolonial dari kekuasaan bangsa yang menjadi konteks penulisan teks,

\footnotetext{
${ }^{1}$ R.S.Sugirtharajah, "A Postcolonial Exploration of Collusion and Construction in Biblical Interpretation", dalam R.S.Sugirtharajah (ed), The Postcolonial Bible. (Sheffield: Sheffield Academic Press, 1998), hlm. 93.

2 R.S.Sugirtharajah, Asian Biblical Hermeneutics and Post colonialism: Contesting the Interpretations, (Orbis Books, Maryknoll, NY., 1998) h. 18-19.

${ }^{3}$ R.S.Sugirtharajah, Asian Biblical Hermeneutics, h. 18.
} 
yang memengaruhi penafsiran teks hingga sekarang. ${ }^{4}$ Untuk itu, artikel ini bertujuan untuk menafsirkan teks Yohanes 9:-40, yang berisikan tentang mujizat Yesus terhadap seorang anak yang buta. Teks ini merupakan narasi yang panjang, yang tidak hanya mendeskripsikan Yesus melakukan mujizat terhadap anak tersebut, merupakan suatu dialog yang berkesinambungan antara anak, orang tua, orang farisi, dan Yesus sendiri.

\section{Metode Penelitian}

Metode yang digunakan dalam menguraikan masalah dalam artikel ini adalah studi eksegesis (kajian tekstual) yang berfokus melakukan kajian pada teks Alkitab, dengan mempertimbangkan konteks yang terjadi di dalam masyarakat. Teks dibaca dalam perspketif orang lemah, dengan membiarkan suara-suara sang liyan sebaagi subjek dalam penafsiran teks Alkitab.

\section{Pembahasan}

Yohanes 9:1-40 menampilkan narasi (mukjizat) tentang Yesus yang menyembuhkan anak yang buta sejak lahir. Mukjizat ini merupakan salah satu dari mukjizat yang tidak ditemukan di dalam Injil sinoptis. ${ }^{5}$ Ciri dari mukjizat di dalam Yohanes ini, mengungkapkan pandangan yang berbeda dengan mukjizat-mukjizat lainnya, dalam arti mukjizat tersebut tidak mengungkapkan iman yang ditimbulkan oleh mukjizat, melainkan lewat perkataan dan pemberitaan Yesus. ${ }^{6}$ Bagi beberapa ahli, mukjizat ini perlu dilihat dalam konteks yang lebih luas, karena ada beberapa hal yang ingin disampaikan oleh pengarang dan penyunting Injil Yohanes. ${ }^{7}$ Pandangan tersebut dibagi ke dalam dua bagian besar yaitu; Pertama, pengusiran dan reaksi orang Yahudi kepada anak yang buta, merupakan gambaran dari nasib murid Yesus setelah satu dekade karya Yesus. Kedua, menjelaskan proses penyembuhan dan pembangunan dari proses yang kompleks dari seorang anak yang “diciptakan", lahir, bertumbuh, dan dewasa. ${ }^{8}$

Pada ayat 1 dan 2, Murid-murid bertanya kepada Yesus, yang disapa dengan Rabi, bahwa "siapakah yang berbuat dosa, orang ini sendiri atau orang tuanya, sehingga ia dilahirkan buta?” Jelas, bahwa murid Yesus menghubungkan antara kebutaan dari anak ini, dengan perbuatan dosa yang dilakukan oleh orang tuanya. ${ }^{9}$ Untuk hubungan tersebut, akan menjadi ganjal untuk menyebutkan seorang bayi atau anak yang baru lahir dan buta disebabkan oleh

\footnotetext{
${ }^{4}$ R.S.Sugirtharajah, The Bible and the Third World; Precolonial, Colonial, Postcolonial, (Cambridge: Cambridge University Press, 2004), h. 250-251

${ }^{5}$ Juga beberapa mujizat di dalam Yohanes lainnya seperti: Kebangkitan Lazarus (11:1 dyb) dan Orang Lumpuh (5:1 dyb)

${ }^{6}$ Willi Marxsen, Pengantar Perjanjian Baru: Pendekatan Kritis Terhadap Masalah-Masalahnya, (Jakarta: BPK Gunung Mulia, 2005), h. 312

${ }^{7}$ Thomas L. Brodie, The Gospel According to John, A Literary and Theological Commentary, (New York: Oxford University Press, 1997), h. 343

${ }^{8}$ Thomas L. Brodie, The Gospel According to John., h. 344

${ }^{9}$ Tidak bermaksud mengatakan bahwa murid Yesus memiliki pandangan, bahwa dosa yang dilakukan oleh orang tua dari anak tersebut mengakibatkan dia buta. Melainkan murid Yesus bisa saja mempertanyakan terntang kebutaan anak tersebut, dan dengan transformasi jiwa dan dosa kepada Yesus karena mereka sudah mendengar akan hal tersebut dan ingin mengetahui langsung pandangan Yesus.
} 
dosa dari orang tua. Namun, bisa saja ini merupakan gema dari beberapa ayat dalam tradisi Yahudi yang seperti tertera di dalam Perjanjian Lama, misalnya dalam Keluaran 20:5. ${ }^{10}$

Tanggapan Yesus terhadap pertanyaan murid-Nya memiliki beberapa poin penting. Pertama, Yesus tidak menyetujui adanya hubungan penderitaan seorang anak dengan dosa yang dilakukan oleh orang tuanya. Meskipun demikian, Yesus tidak menyangkal ada hubungan antara penderitaan dan dosa ${ }^{11}$, namun itu tidak bisa disalurkan/ditularkan dari orang tua kepada anaknya. ${ }^{12}$ Pandangan Yesus ini kemudian ditransformasi ke keluarga, di mana menurut Yesus, "karena Pekerjaan-Pekerjaan Allah harus dinyatakan di dalam dia." Jadi penderitaan yang terjadi bagi anak yang terlahir buta saat ini, harusnya dilihat sebagai cara Allah menyatakan pekerjaan-Nya. Dengan kata lain, Yesus menarik konsep penderitaan ke dalam konteks yang lebih positif. ${ }^{13}$ Artinya, orang yang dianggap buruk dan hampir tidak bernyawa pun dianggap sebagai bagian dari karya Allah. ${ }^{14}$

Kedua, Yesus ingin membuka perspektif murid-murid-Nya mengenai anak yang terlahir buta. Yesus melakukan transformasi terhadap pemikiran murid, yang menghubungkan antara anak terlahir buta dengan dosa dari orang tuanya. Perubahan perspektif yang dilakukan oleh Yesus bagi murid adalah melihat anak yang penyandang disabilitas sebagai manifestasi dari karya Allah yang telah dibebankan (diberikan) bagi Yesus (Yoh. 5:19 \& 36). Ayat 4 memperjelas tugas dan panggilan para murid untuk meneruskan bersama tugas-tugas Yesus. Bahkan ini bukan hanya dilihat sebagai suatu tugas, melainkan suatu keharusan dari rencana Allah yang mengutus Yesus untuk merangkul mereka. ${ }^{15}$

Adegan di dalam ayat 8-12 menggambarkan keadaan setelah orang buta itu disembuhkan, dan dia sudah bisa berbicara dengan tetangga-tetangga yang mempertanyakan penglihatannya. Sebelumnya, pada ayat 6-7 terjadi penyembuhan oleh Yesus dengan cara yang sangat kuratif (yaitu menggunakan tanah dan ludah), dan menyuruh orang buta tersebut membasuh dirinya di Siloam. Setelah ia bisa melihat lagi ayat 8-9 mencatat percakapan antara para tetangga, sedangkan anak tersebut masih pasif. Baru setelah itu anak itu menggunakan kata Benar, Akulah itu, yang menandakan gema dari pasal sebelumnya, pasal 8:24, 28 dan 58. ${ }^{16}$ Penggunaan kata ini menurut beberapa ahli, ${ }^{17}$ menegaskan kembali gambaran dan karya Allah di dalam anak yang dulunya terlahir buta. Menurut saya, jawaban yang diberikan oleh anak tersebut merupakan pengakuan akan identitasnya. ${ }^{18}$ Dia tidak takut untuk menyatakan

\footnotetext{
${ }^{10}$ Terhadap penyebab kebutaan ini, banyak para Ahli yang menghubungkan pemahaman orang Yahudi tentang tranfsormasi jiwa. Meskipun di dalam Yohanes 9 ayat 2 sama sekali tidak menghubungkan dan menekankan pandangan orang Yahudi pada umumnya, namun mereka melihat murid Yesus sebagai representasi dari pandangan orang Yahudi pada umumnya.

${ }^{11}$ Di dalam Lukas 13:2-5 dan 14 Yesus tidak menolak antara dosa dan penderitaan.

${ }^{12}$ Herman Ridderbos, The Gospel of John: A Theological Commentary, h. 333

${ }^{13}$ Thomas L. Brodie, The Gospel According to John., h. 345-346

${ }^{14}$ Ibid,h. 345, Nada yang sama juga terdapat dalam Yohanes 11:4. Ridderbos menegaskan bahwa, penekanan pada pemahaman Allah terlibat dalam penderitaan anak yang buta bukan berarti menjadikan Allah sebagai penyebab dari kebutaan anak tersebut, melainkan Allah turut terlibat dengan apa yang terjadi sekarang dengan anak buta tersebut. Herman Ridderbos, The Gospel of John: A Theological Commentary, h. 333

${ }^{15}$ Bnd. 4:34; 5:17; $10: 32$

${ }^{16}$ Ego Eimi di dalam pasal 8 hanya digunakan oleh Yesus dan merujuk kepada Allah.

${ }^{17}$ Thomas L. Brodie, The Gospel According to John., h. 351

${ }^{18}$ Troel Engberg-Pedersen, John and Philosophy; A New Reading of the Fourth Gospel, (Oxford: Oxford University Press,2017), h. 215-216
} 
identitasnya sebagai orang buta, sekaligus sebagai orang yang menerima mukjizat dari Yesus. Pengakuan seperti ini merupakan titik penting dari seorang yang termarjinalisasi dalam suatu masyarakat, dalam konteks tertentu, tetapi berani untuk bersuara dan berpendapat.

Selanjutnya, pada bagian 13-17 merupakan saat bagi orang buta itu menjawab pertanyaan-pertanyaan terhadap dirinya, terutama kepada proses penyembuhan yang terjadi. Jawaban yang diberikan oleh orang buta ini ditulis seperti verbatim. Ia mengatakan, bahwa "Ia mengoleskan adukan tanah pada mataku, lalu aku membasuh diriku, dan sekarang aku dapat melihat." Tanggapan orang Farisi terhadap jawaban orang buta itu, memiliki dua sudut pandang. Yang pertama, mereka berpusat pada tindakan Yesus yang melakukan "penyembuhan" pada hari Sabat, yang menggambarkan Yesus bukan berasal dari Allah, dan sebagian lagi berfokus pada seorang berdosa (menunjuk pada Yesus menurut orang Farisi) bisa melakukan mukjizat sedemikian rupa. Menurut Brodie, ${ }^{19}$ hal ini menggambarkan suatu pengulangan dari ayat 9:1-3 yang menjelaskan dua paradoks yaitu "dari Allah" dengan "orang berdosa." Brodie juga menyatakan, bahwa dalam kasus "penglihatan" ini, bukan dipusatkan kepada siapa yang buta, melainkan orang yang memberi penglihatan. ${ }^{20}$

Jawaban dari anak terlahir buta bagi orang Farisi pada ayat 17 sangat menarik untuk diperhatikan. Orang Farisi memberikan kepada dia dua opini tentang Yesus, yaitu "bukan berasal dari Allah" dan "orang berdosa," dan anak yang terlahir buta ini malah memutuskan untuk menyebut Yesus sebagai seorang nabi (ay. 17). Keputusan dia untuk menyebut Yesus sebagai seorang Nabi menggambarkan, bagaimana proses ia membangun persepsinya tentang seseorang yang menyembuhkan matanya, yang sudah buta sejak lahir. Pernyataan Yesus sebagai nabi, merupakan penegasan yang dilakukan sejak awal, karena pada ayat 39 akan menjelaskan panggilan Yesus untuk "penghakiman," yang mana menjadi tugas-Nya datang ke dunia. $^{21}$

Ayat 18-23: (Keterlibatan orang tua dan anak yang dewasa bertanggung jawab atas dirinya sendiri). Kisah pada ayat 18-23 memuat bagian yang baru. Anak buta itu tidak dilihat sebagai seseorang yang tiba-tiba bisa melihat, melainkan dilihat sebagai seseorang yang secara jelas berbeda dengan orang tuanya. Sedangkan, peran orang tua di sini adalah berhadapan dengan orang-orang Yahudi yang tidak percaya, bahwa anak tersebut sejak awal terlahir buta dan disembuhkan. Peran orang tua di dalam ayat 18-23 sebagai berikut: Pertama, orang tua melakukan pengakuan, bahwa anak yang kini bisa melihat, adalah anak mereka yang buta sejak lahir. Orang tua tidak menyangkal anak mereka, sekalipun mereka diinterogasi oleh orang-orang Yahudi (ay. 20). Kedua, orang tua menegaskan pengetahuan mereka hanya terbatas pada apa yang terjadi di luar (eksternal) anak tersebut, atau apa yang bisa mereka lihat. Sedangkan, untuk fenomena ataupun proses bagaimana anak itu melihat, dan dari siapa penglihatan itu, adalah bagian yang sama sekali mereka tidak tahu. Dari peran orang tua di atas terlihat dengan jelas, kedewasaan bukan berasal dari orang tua. Kedewasaan anak itu berasal dari penglihatan yang diperolehnya, untuk itu ia bisa berbicara mewakili dirinya sendiri, bukan orang tuanya.

\footnotetext{
${ }^{19}$ Thomas L. Brodie, The Gospel According to John., h. 349

${ }^{20}$ Ibid

${ }^{21}$ Herman Ridderbos, The Gospel of John: A Theological Commentary, h. 340
} 
Pada ayat 22, sang narator menggambarkan orang tua menjadi takut untuk memberikan pernyataan, yang akan dianggap sebagai pengakuan Yesus adalah Mesias. Untuk itu, mereka membiarkan orang-orang tersebut, untuk menanyakan langsung kepada anak itu. Sikap tersebut, memberikan kebebasan dan kemerdekaan yang fundamental bagi anak untuk bertanggung jawab atas dirinya sendiri. Bagi saya, orang tua pada akhirnya memperlakukan anak mereka sama seperti dirinya, sama seperti orang lain. Tidak ada pembedaan khusus, apakah anak itu sudah bisa melihat lagi, apakah anak itu masih buta, orang tua tetap memperlakukan dia sebagai seorang anak yang sudah dewasa yang bertanggung jawab bagi dirinya.

Interogasi yang kedua kalinya terjadi pada ayat 23-24. Setelah mendapatkan penegasan oleh orang tua sebagai "orang dewasa," anak yang dulunya buta tersebut kembali dipanggil oleh orang-orang untuk diinterogasi. Interogasi yang kedua ini juga sangat menentukan nasib anak tersebut, di hadapan orang-orang banyak yang ingin mengetahui penglihatan dia. Pada ayat 24, interogasi yang dilakukan tidak lagi berpusat pada apakah benar mukjizat penyembuhan itu terjadi. Interogasi tersebut bertujuan untuk mencari cara menyalahkan Yesus. Interogasi ini menggunakan otoritas dengan penggunaan kata "Katakanlah kebenaran di hadapan Allah."22 Bagi Brodie, penggunaan formula kalimat "Give glory to God" atau "Give Praise to God," digunakan dalam dua artian. Yang pertama, formula kalimat tersebut digunakan untuk mengingatkan umat pilihan Allah untuk memuji Tuhan. Penggunaan yang kedua formula kalimat tersebut, adalah untuk membuat pengakuan orang yang bersalah untuk menghormati Allah lewat rasa bersalah mereka. Misalnya ditemukan di dalam (Yos 7:19, 1 Sam. 6:5, dan sebagainya). Jadi, formula kalimat ini merupakan panggilan untuk beribadah (menyembah dan memuji Tuhan), tetapi juga sebagai penyerahan dan pengakuan (atas kesalahan). ${ }^{23}$

Bagi mereka "kami tahu" Yesus adalah orang berdosa, sekaligus bukan Nabi dari Allah. Penggunaan kata "orang itu berdosa" pada kalimat selanjutnya, bukan hanya kutukan dan hukuman yang fundamental bagi Yesus, melainkan suatu kontradiksi dengan apa yang dikatakan oleh orang yang dulu buta, bahwa Yesus adalah seorang Nabi. Jadi, selain kutukan dan konfrontasi melawan Yesus, orang-orang Yahudi itu juga melakukan kontradiksi, terhadap apa yang mereka dengar dari anak yang dulu terlahir buta.

Anak yang terlahir buta (pada ayat 25-26) kembali menegaskan fakta yaitu ia yang dulu buta, kini bisa melihat. Pada bagian ini, ia masih diinterogasi oleh orang-orang Yahudi yang mencoba terus-menerus melakukan kontradiksi dengan perbuatan Yesus. Interogasi yang terus berlanjut itu, mencapai puncaknya (ay. 27-29) ketika anak yang dulunya buta berperan sebagai pihak yang bertahan menjadi pihak yang melawan, ia yang dulu diinterogasi oleh orang Yahudi, kini menjadi interogator. Misalnya, anak tersebut mengatakan "kamu mau menjadi murid-Nya juga?" (ay. 27). orang-orang Yahudi pun membalas anak tersebut dengan memberikan suatu kalimat yang berlawanan untuk membuat anak tersebut menjadi inferior. Bagi mereka, mereka adalah murid Musa, sedangkan anak tersebut adalah murid-Nya (merujuk pada Yesus). Jelas merupakan suatu sikap yang membedakan antara murid Musa,

\footnotetext{
${ }^{22}$ Thomas L. Brodie, The Gospel According to John., h 349

${ }^{23}$ Ibid.h. 350
} 
yang merupakan nabi yang langsung berbicara dengan Allah, dengan Yesus yang selalu mereka lawan.

Serangan balik dari orang Yahudi tersebut menggunakan tradisi Taurat (yang menghubungkan Musa), yang nantinya pada ayat 30-33 ditentang oleh anak yang dulunya terlahir buta. Yang ditentang oleh anak tersebut bukanlah tradisi yang disinggung oleh orang Yahudi, tetapi ia memberikan suatu kepada orang yang baru saja menyembuhkan matanya, sebagai orang yang diutus langsung dari Allah. Reaksi orang Yahudi pada ayat 34 terhadap pernyataan anak tersebut adalah mengusirnya ke luar Sinagoge.

Tanggapan orang Yahudi terhadap anak tersebut, bahwa "Ia terlahir dalam dosa," menurut Ridderbos ${ }^{24}$ yang dimaksud dengan terlahir dalam dosa (menurut orang Yahudi), yaitu keadaan di mana anak itu terlahir sebagai orang buta, itu berarti kebutaannya dilihat sebagai hukuman atas dosanya. Menurutnya, ${ }^{25}$ orang Yahudi pasti mengetahui, bahwa keberdosaan merupakan bagian dari setiap manusia yang terlibat sejak dia lahir. Jadi setiap orang adalah berdosa dan terlibat sejak ia berada. Namun, untuk kasus anak yang buta ini, kebutaan dilihat hanya sebatas akibat dari dosa, dan hukuman yang harus ditanggung akibat perbuatan orang lain (orang tua).

Puncak dari narasi mukjizat ini ketika Yesus muncul kembali dan berperan sebagai pihak yang berlawanan dengan orang Yahudi dan Farisi(Ayat 35-41). Yesus kemudian bertanya kepada mereka "Percayakah engkau kepada Anak Manusia?" Ini merupakan pertanyaan afirmatif yang akan dijawab nantinya pada ayat 37 , dan pertanyaan tersebut merujuk kepada Yesus, bukan kepada anak yang terlahir buta.

Ayat 39 merupakan awal dari kesimpulan dalam kisah Yohanes 9. Kehadiran Yesus di dunia kembali ditegaskan dengan kata "penghakiman." Yesus juga menghubungkan dirinya sebagai Terang Dunia. Tetapi tujuan Yesus datang ke dunia sebagai terang dunia tidak hanya terbatas pada kebutaan secara fisik. Kebutaan tidak hanya terbatas pada fisik melainkan orang-orang yang dibutakan oleh keinginan untuk melakukan konfrontasi terhadap Yesus.

Pada bagian terakhir dari pasal 9 (ayat 40-41) menggambarkan dua hal. Pertama, bagi Yesus yang namanya dosa adalah ketika seseorang mengaku tidak berdosa, dan tidak membutuhkan pengampunan dari penghakiman yang akan datang. Dalam hal ini, Yesus menganalogikan dirinya sebagai terang dunia, yang datang kepada orang yang buta. Kehadiran-Nya dibutuhkan bagi keadaan manusia yang terlahir dalam kondisi keberdosaan (Yoh. 5:14; 8:24; 3:36 dll.). Di sini, Yesus menuntut kesadaran manusia, bahwa semua orang memiliki dosa, dan Yesuslah sebagai tokoh sentral untuk memberikan anugerah penyelamatan bagi manusia. Kedua, keadaan berdosa manusia bukan yang memutuskan hubungan manusia dengan apa yang akan diberikan Yesus (penyelamatan) sebagai Terang Dunia, melainkan ilusi seseorang bisa menyelamatkan dirinya sendiri tanpa Yesus sebagai Terang dunia, untuk itu dosa selalu ada. Jadi yang membuat manusia kehilangan arah tujuan keberimanannya adalah penyangkalan akan anugerah dari Tuhan lewat Yesus. (Bnd. Yoh. 3:16). ${ }^{26}$

\footnotetext{
${ }^{24}$ Herman Ridderbos, The Gospel of John: A Theological Commentary, h.346

${ }^{25}$ Ibid

${ }^{26}$ Herman Ridderbos, The Gospel of John: A Theological Commentary, h. 351
} 


\section{Menemukan Relevansi Yohanes 9:1-40 dengan Pendekatan Postkolonial}

Ada beberapa hal yang dapat dimengerti dari Yohanes 9:1-40.

Pertama, Menurut penulis Yohanes, Yesus adalah sang tokoh tranformis yang melakukan perubahan pemahaman para murid bagi anak yang terlahir buta. Artinya, kebutaan merupakan cara, dan karya Allah untuk menyatakan kuasanya. Dalam penafsiran di bagian awal, kita melihat sosok Yesus dan kehadiran-Nya di tengah dunia, sebagaimana yang digambarkan dalam terang dunia, membuat Yesus menyelamatkan kehidupan manusia yang penuh dosa. Sikap Yesus tidak hanya terbuka terhadap orang-orang yang didiskriminasikan di dalam masyarakat, tetapi memberi tempat bagi mereka sebagai orang-orang yang layak diselamatkan, dan berlaku bagi semua orang. ${ }^{27}$ Namun, jika kita perhatikan dengan seksama dan dan menjadikan si anak penyandang disabilitas sebagai suatu subjek dan identitas yang tidak bisa ditawar menawar, maka apa yang dilakukan Yesus dalam mukjizat ini, sebagai bentuk upaya melakukan "penormalan" terhadap anak yang terlahir buta sejak lahir.

Mukjizat-mukjizat penyembuhan yang dilakukan oleh Yesus, seringkali dipahami sebagai penyataan kuasaNya, namun secara implisit menunjukkan bahwa ada upaya untuk melihat penyandang disabilitas sebagai pihak yang perlu diubah dan menjadikan mereka sebagai orang normal seperti lainnya, sehingga mereka bisa diterima dalam lingkungan keluarga, masyarakat, bahkan lingkaran Yesus itu sendiri. Hal ini berdampak pada penafsiran dan diskriminasi terhadap para penyandang disabilitas dalam konteks kolonial, hingga postkolnial.

Kedua, secara keseluruhan, kisah Yohanes 9:1-40 menegaskan hal-hal yang menyangkut dengan dosa dan keselamatan yang berasal dari Yesus. Pada penjelasan ayat 1-12, peneliti menegaskan, bahwa kebutaan sama sekali tidak bisa dihubungkan dengan akibat dosa yang berasal dari orang tua kepada anak. Itu bukan berarti mengatakan anak tidak berdosa, sebab manusia tidak mungkin lepas dari perbuatan salah yang dalam perspektif keberagamaan seseorang dapat dikategorikan sebagai dosa. Pemahaman seperti ini sangat penting dalam konteks postkolonial, di mana orang dengan kebutuhan khusus atau dalam hal ini penyandang disabilitas serta orang tuanya sering dilihat sebagai orang-orang yang tidak berguna dan sering menjadi pihak yang bersalah, untuk itu seringkali mereka diasingkan, atau tidak diterima di lingkungan masyarakat. Tetapi apa yang dilakukan oleh Yesus adalah merangkul dan menerima mereka. Bahkan melakukan transformasi bagi orang lain (murid, orang Farisi dan Yahudi) yang menganggap suatu kondisi kebutaan sebagai bagian dosa. Yesus menunjukkan sikap menerima dan belas kasih yang sangat penting dilakukan oleh kita kepada orang lain, terutama dalam hal ini penyandang disabilitas, maupun kelompok minoritas seperti LGBT, anak, dan sebagainya. ${ }^{28}$

Ketiga, strategi yang dilakukan oleh anak yang terlahir buta adalah dengan menyatakan dengan tegas bahwa "akulah itu", ini adalah suatu penegasan identitas dari seorang anak yang terlahir buta yang kemudian mendapatkan mukjizat dari Yesus. Upaya yang dilakukan anak 2016.

${ }^{27}$ Vincent K. Wenno, Tesis Anak Homoseksual dan Transgender di tengah Keluarga, UKDW Yogyakarta

${ }^{28}$ Dan O. Via \& Robert A. J. Gagnon, Homosexuality and the Bible: Two Views, (Minneapolis: Fortress Press, 2003), h. 6 
tersebut, merupakan pengakuan akan identitasnya, sekalipun di sisi lain orang tua tidak mengakui bahwa itu adalah anak mereka karena berbagai alasan. Di sini, anak memberikan penegasan bahwa dia berani bersuara sekaligus diperhadapkan dengan suara lain yang mendominasi.

\section{Kesimpulan}

Fokus pada upaya menyuarakan indentitas penyadang disabilitas dalam konteks Indonesia memiliki masalah yang cukup signifikan. Sebagaimana penyandang disabilitas dan kelompok lainnya dianggap minoritas. Ide tentang manusia dikonstruksi sebagai manusia yang "normal" yang tak "bercacat", sehingga orang dengan perbedaan yang kelihatan atau tidak dianggap sebagai suatu kontradiksi dari "kenormalan", yang perlu didiskriminasikan, dan disingkirkan dengan cara diabaikan dalam kebijakan publik yang melingkupi ekonomi, budaya, sosial, dan terutama adalah upaya politik. Untuk itu, perlu untuk memikirkan kembali penafsiran teks Alkitab yang secara langsung atau tidak, mendiskrimasikan penyandang disabilitas dan kaum minoritas yang lainnya.

\section{Referensi}

Brodie, Thomas L., The Gospel According to John, A Literary and Theological Commentary, New York: Oxford University Press, 1997

Engberg-Pedersen, T., John and Philosophy; A New Reading of the Fourth Gospel, Oxford: Oxford University Press, 2017

Marxsen W., Pengantar Perjanjian Baru: Pendekatan Kritis Terhadap Masalah-Masalahnya, Jakarta: BPK Gunung Mulia, 2005

Ridderbos, H., The Gospel of John: A Theological Commentary, UK: Oxford, 2005

Sugirtharajah, R.S.Asian Biblical Hermeneutics and Post colonialism: Contesting the Interpretations, Orbis Books, Maryknoll, NY., 1998

The Bible and the Third World; Precolonial, Colonial, Postcolonial, Cambridge: Cambridge University Press, 2004

Sugirtharajah, R.S. (ed) The Postcolonial Bible, Sheffield: Sheffield Academic Press, 1998

Via, Dan O., \& Gagnon, R. A. J., Homosexuality and the Bible: Two Views, Minneapolis: Fortress Press, 2003

Vincent K. Wenno, Thesis UKDW, Anak Homoseksual dan transgender di tengah keluarga 2016 Yogyakarta 